\title{
A ' $G$ ' chromosome banding study of three cupped oyster species: Crassostrea gigas, Crassostrea angulata and Crassostrea virginica (Mollusca: Bivalvia)
}

\author{
Alexandra Leitão ${ }^{\mathrm{a}, \mathrm{c}}$, Catherine Thiriot-Quiévreux ${ }^{\mathrm{a} *}$, \\ Pierre Boudry $^{\mathrm{b}}$, Isabel Malheiro ${ }^{\mathrm{c}}$ \\ a Observatoire océanologique, Université P. et M. Curie, CNRS-INSU, \\ BP 28, 06230 Villefranche-sur-Mer, France \\ b Laboratoire de génétique et pathologie, Station Ifremer, \\ BP 133, 17390 La Tremblade, France \\ c Instituto de ciências biomédicas de Abel Salazar, Universidade do Porto, \\ Lg. Prof. Abel Salazar 2, 4000 Porto, Portugal
}

(Received 26 May 1999; accepted 12 August 1999)

\begin{abstract}
The G-banding technique was performed on chromosomes from gill tissue of three cupped oyster species: Crassostrea gigas, Crassostrea angulata and Crassostrea virginica. Identification of the ten individual chromosome pairs was obtained. Comparative analysis of G-banded karyotypes of the three species showed that their banding patterns generally resembled each other, with chromosome pair 3 being similar in all three species. However, differences from one species to another were also observed. The G-banding pattern highlighted greater similarities between $C$. gigas and $C$. angulata than between these two species and $C$. virginica, thus providing an additional argument for genetic divergence between these two evolutionary lineages. $C$. gigas and $C$. angulata showed a different G-banding patterns on the two arms of chromosome pair 7 , which agrees with their taxonomic separation. The application of this banding technique offers a new approach to specific problems in oyster taxonomy and genetics. (C) Inra/Elsevier, Paris
\end{abstract}

chromosome / G-banding / Crassostrea gigas / Crassostrea angulata / Crassostrea virginica

* Correspondence and reprints
E-mail: thiriot@ccrv.obs-vlfr.fr 
Résumé - Étude du marquage chromosomique en bandes G chez trois espèces d'huîtres creuses : Crassostrea gigas, Crassostrea angulata et Crassostrea virginica. Le marquage chromosomique en bandes $\mathrm{G}$ a été réalisé sur des chromosomes obtenus à partir de tissu branchial de trois espèces d'huîtres creuses, Crassostrea gigas, Crassostrea angulata et Crassostrea virginica, et a permis l'identification des dix paires de chromosomes de ces espèces. L'analyse comparée des caryotypes marqués en bandes $\mathrm{G}$ a montré que les principales bandes $\mathrm{G}$ présentaient un modèle proche chez les trois espèces, la paire de chromosome 3 étant identique. Cependant quelques différences ont pu être observées. Les caryotypes de $C$. gigas et $C$. angulata ont révélé plus de similitudes entre eux qu'avec celui de $C$. virginica. Ceci apporte un argument supplémentaire à la divergence génétique entre ces deux lignées évolutives. C. gigas et $C$. angulata montrent un marquage en bandes $\mathrm{G}$ différent sur les deux bras de la paire du chromosome 7 , ce qui corrobore leur séparation taxinomique. L'application de cette technique apporte une nouvelle approche pour la taxinomie et la génétique des huîtres. (c) Inra/Elsevier, Paris

chromosome / bandes G / Crassostrea gigas / Crassostrea angulata / Crassostrea virginica

\section{INTRODUCTION}

Cytogenetic investigations in oysters were first mainly concerned with data on chromosome number and gross morphology (e.g. [1, 22]). Later, morphometric analyses of karyotypes provided the characterisation of chromosome morphology based on centromeric position (e.g. [13, 17, 31, 37]). These studies showed that oyster karyotypes were symmetrical and interspecific differences consisted in the occurrence and differing proportions of metacentric and submetacentric chromosomes $[18,21]$.

The application of differential staining techniques, such as Ag-NORs for nucleolar organiser regions and $\mathrm{C}$-banding for constitutive heterochromatin allowed the identification of some specific chromosome pairs in the karyotypes of oyster species [14-16, 18, 19, 39]. More recent techniques, such as fluorescent in situ hybridization, have been tested in Crassostrea gigas [5, 9], and others, such as fluochrome staining and restriction endonuclease treatment, have been carried out in other bivalve species $[25,26]$. But although the data obtained using these differential staining techniques provide a better knowledge of the karyotypes of bivalve species, they do not allow the identification of all individual chromosomes.

The G-banding technique, defined as a system of alternating dark and light bands throughout the length of the euchromatic parts of chromosomes [35], allows the identification of each individual chromosome which enables one to prepare precise and detailed karyotypes. This technique has been routinely used in vertebrate cytogenetics, especially in mammals (e.g. [11, 12, 34, 41]). Only a few studies have focused on lower vertebrates, such as fishes (e.g. [2, 6, 7, 24]) and on invertebrates such as insects (e.g. [4, 23, 33]). Among bivalves, G-banding patterns have been attempted in Mytilus [25, 27] and in the oyster Crassostrea virginica [32].

In this study, G-banding patterns are described in three cupped oysters: Crassostrea gigas (Thumberg), the Pacific oyster, Crassostrea angulata (Lamark), the Portuguese oyster and Crassostrea virginica (Gmelin), the Eastern American oyster. 


\section{MATERIALS AND METHODS}

\subsection{Biological material}

Specimens of each taxon were reared at the Ifremer hatchery in La Tremblade (Charente-Maritime, France). Specimens of Crassostrea gigas were collected from the Seudre estuary, where this species was introduced from Japan [8] and is currently farmed on a large scale. Specimens of Crassostrea angulata were collected in Setubal bay (Portugal), then acclimated at the Ifremer hatchery. Their taxonomic status was assessed using mitochondrial DNA markers as described in Boudry et al. [3]. Specimens of Crassostrea virginica were imported from a wild population located in Shippagan, New Brunswick (Canada) and acclimated at the Ifremer hatchery. These oysters were maintained in common quarantine facilities until reproduction, and their progenies were sampled for chromosome analysis.

\subsection{Chromosome preparation}

Whole juvenile animals were incubated for $7-9 \mathrm{~h}$ in a $0.005 \%$ solution of colchicine in seawater. Because cell cultures are not yet available for molluscs, we used growing somatic tissues such as gills as a source of mitoses. After dissection, gills were treated for $30 \mathrm{~min}$ in $0.9 \%$ sodium citrate. The material was fixed in a freshly prepared mixture of absolute alcohol and acetic acid (3:1) with three changes of $20 \mathrm{~min}$ each. Slide preparations were made from pieces of gill tissue from each individual, using an air drying technique [38].

\subsection{G-banding}

G-banding was performed by the ASG method (acetic/saline/Giemsa) after Sumner et al. [36]. Chromosome preparations were treated for $1 \mathrm{~h}$ at $60^{\circ} \mathrm{C}$ in $2 \times \mathrm{SSC}(0.3 \mathrm{M}$ sodium chloride: $0.03 \mathrm{M}$ trisodium citrate). After rinsing in distilled water, the slides were stained with $2 \%$ Giemsa-stain in phosphate buffer, $\mathrm{pH} 6.8$ for $90 \mathrm{~min}$. Best results were obtained by banding within 510 days of chromosome preparation.

Photographs of G-banded metaphases were taken with a Zeiss III photomicroscope. Karyotypes were made on the basis of length, centromeric position and banding pattern. Because we were working with somatic tissues, we had to use many animals to obtain a sufficient number of mitoses. Moreover, the latter showed different levels of condensation making the number of cells we could work on even smaller. Thus, in total, $18 \mathrm{G}$-banded karyotypes were examined in C. gigas, 20 in C. angulata and 21 in C. virginica.

\section{RESULTS}

Establishing a repetitive G-banding pattern requires a similar degree of condensation of chromosomes to be compared. Although a large number of metaphases was observed, we selected only those with similar degrees of condensation for interpretation. 
Figure 1 presents an example of a G-banded metaphase of one of the three species studied, C. gigas. In figure 2, haploid G-banded karyotypes are shown to facilitate comparison of homologous chromosome pairs between the three species studied. The karyotype of $C$. gigas consists of ten metacentric chromosomes, that of $C$. angulata has nine metacentric and one submetacentric (no. 8) and the karyotype of $C$. virginica includes eight metacentric and two submetacentric (nos 4 and 8) chromosomes [18].

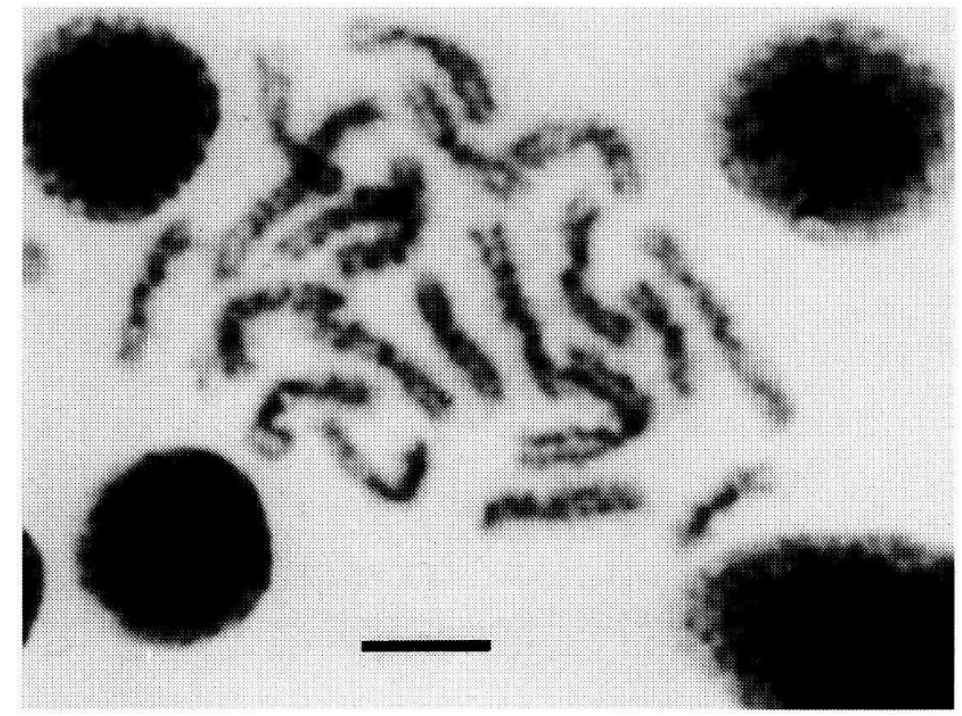

Figure 1. G-banded metaphase of Crassotrea gigas. Bar $=5 \mu \mathrm{m}$.

\section{cg ca cv}

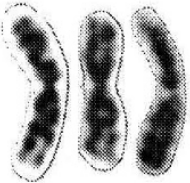

1

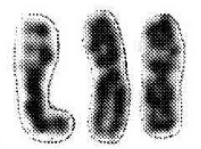

6

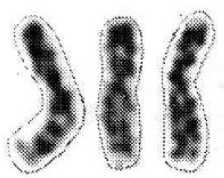

2

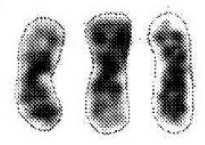

7

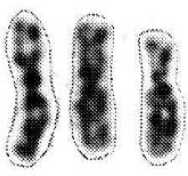

3

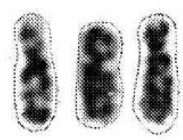

8

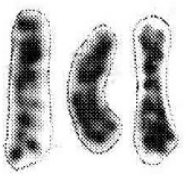

4

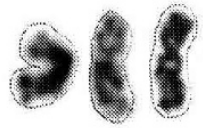

9

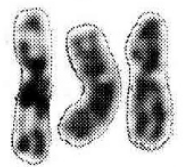

5

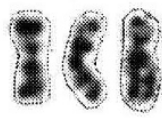

10

Figure 2. Haploid G-banded karyotypes. cg: Crassostrea gigas, ca: Crassostrea angulata, cv: Crassostrea virginica. Bar $=5 \mu \mathrm{m}$.

Figure 3 gives a schematic representation of the G-banding patterns obtained for the three species. Owing to differences in condensation of chromosomes only 


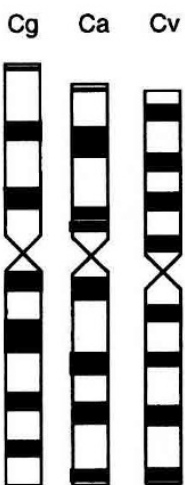

1

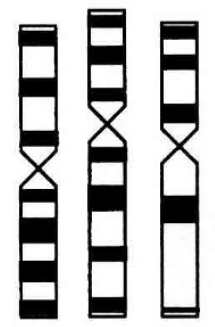

6

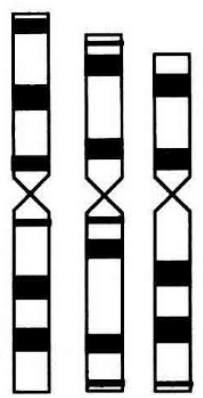

2

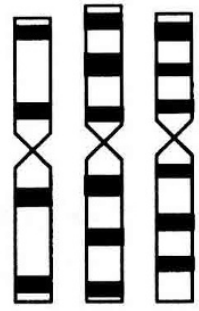

7

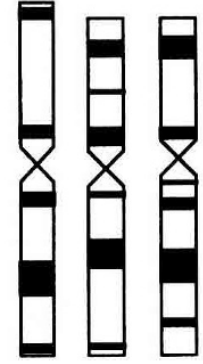

3

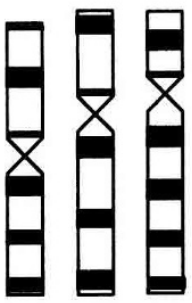

8

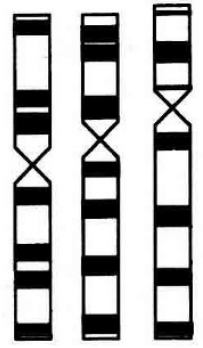

4

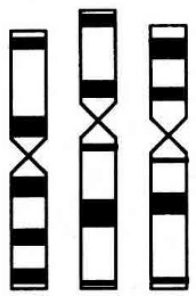

9

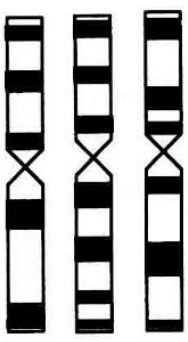

5

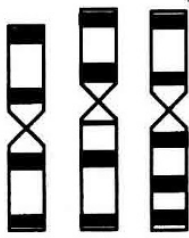

10

Figure 3. Comparative ideogram of G-banding patterns in Crassostrea gigas (cg), Crassostrea angulata (ca) and Crassostrea virginica (cv).

major G-bands were used to compare the three species, with an emphasis on their number rather than their position.

Chromosome 1: on the short arm, both $C$. gigas and $C$. angulata show two major bands, while in $C$. virginica four major bands are present. All three species present four bands on the long arm.

Chromosome 2: on the short arm, $C$. gigas shows three bands while in $C$. angulata and $C$. virginica two major bands are present. On the long arm, the three species are characterised by two major bands.

Chromosome 3: the pattern is very similar across the three species, being characterised by two major bands at the extremities of the short arm and one large band at the centre of the long arm.

Chromosome 4: on the short arm, in C. gigas and in C. angulata, the bands are observed in subtelomeric and near centromeric positions while $C$. virginica is characterised by one centrally located major band. Four bands are located on the long arm of the three species differing slightly in their position, which was probably caused by the different degrees of condensation of the chromosomes.

Chromosome 5: the three species present three bands on the short arm. On the long arm, the G-banding pattern is different between the three species. 
Chromosome 6: on the short arm, three bands are observed in the three species. On the long arm, C. gigas and $C$. angulata show four successive bands, while in $C$. virginica the banding pattern is characterised by the presence of only one major median band.

Chromosome 7: C. gigas shows two bands on the short arm and two on the long arm. In $C$. virginica and $C$. angulata, three bands are seen on both the short arm and the long arm. These differ slightly in intensity and position.

Chromosome 8: the short arm in all three species is characterised by the presence of one major band. There are three major bands on the long arm of $C$. gigas and $C$. angulata and four bands in $C$. virginica.

Chromosome 9: on the short arm, two bands are seen in the three species. On the long arm, $C$. gigas presents three near equivalent bands differing from $C$. angulata and $C$. virginica which are characterised by the presence of one major band.

Chromosome 10: the three species are characterised by two bands at the extremities of the short arm. Two major bands are seen on the long arm of $C$. gigas and C. angulata while three are present in C. virginica.

\section{DISCUSSION}

The application of G-banding to three species of oysters: $C$. gigas, $C$. angulata and $C$. virginica, allowed individual identification of the chromosomes which makes it possible to prepare accurate karyotypes and describe the respective idiograms.

Comparison with previous G-banding analysis of $C$. virginica [32] showed that the number of G-bands identified as black bands (i.e. the most distinct) was similar in chromosome pairs 5 and 9 but quite different in the remaining chromosome pairs. This can be explained by i) different karyotypes of the oyster populations studied ( $6 \mathrm{~m}-4 \mathrm{sm}$ in Tabasco, Mexico; $8 \mathrm{~m}-2 \mathrm{sm}$ in our population), ii) different techniques used, iii) different condensation of chromosomes.

The major G-bands of the three Crassostrea species studied here show a similar pattern on the whole chromosome 3 , on the short arms of chromosomes 5 , 6, 8, 9 and 10 and on the long arms of chromosomes 1,2 and 4.C. gigas and $C$. angulata present additional similarities on the short arms of chromosomes 1 and 4, and on the long arms of chromosomes 6,8 and 10. These two taxa, often considered as the same species [28], have been differentiated by mitochondrial DNA analysis [3, 30] and karyotype analysis [18]. G-banding highlights similarities between these two taxa, except for chromosome 7 where both arms are shown to be different. This difference corroborates their taxonomic separation. $C$. angulata and $C$. virginica also display additional similarities in the number of major G-bands on the whole chromosome 7 , the short arm of chromosome 2 and the long arm of chromosome 9, but they differ on the short arms of chromosomes 1 and 4, and on the long arms of chromosomes 5, 6, 8 and 10. Karyological differences between these two species have been previously observed [18]. C. virginica contrasts with $C$. gigas on the short arms of chromosomes $1,2,4$ and 7 , and on the long arms of chromosomes $5,6,7,8,9$ and 10. Genetic divergence between $C$. gigas and $C$. virginica has been demonstrated by molecular phylogenies [20,29] and by karyotype analysis [18]. The 
differences in G-banding pattern between C. gigas and C. virginica substantiate their genetic difference.

Therefore, from the analysis of the banding karyotypes of the three species, we can conclude that they generally resemble each other with chromosome pair 3 being similar in all the three species. However, differences were observed from one species to another, showing that there is a higher resemblance between the banded karyotypes of $C$. gigas and $C$. angulata than between these two species and $C$. virginica.

Because of the economic and ecological importance of oysters, genetic investigations are of special interest. In this respect, the identification of structural chromosomal features could be very useful in gene mapping, hybrid breeding or stock conservation programmes. The individual identification of the chromosomes by G-banding will provide a better knowledge of the aneuploidy phenomenon reported in oysters (e.g. [40]) by identifying missing chromosomes. Similarly, G-banding could also provide a very valuable technique for chromosome segregation studies on triploid and tetraploid oysters [10]. The applications of $\mathrm{G}$ chromosome banding are therefore numerous and represent a useful new tool in oyster genetics.

\section{ACKNOWLEDGEMENT}

This work was supported by a French-Portuguese co-operation (no. $158 \mathrm{C} \mathrm{1)}$, by a research training project (contract no. FAIR GT 97-3599) and part of Genephys program (Contract no. FAIR 95-421). We thank S. Sabini and $\mathrm{S}$. Heurtebise for excellent technical assistance and $\mathrm{H}$. McCombie for advice on the English.

\section{REFERENCES}

[1] Ahmed M., Cytogenetics of oysters, Cytologia 38 (1973) 337-346.

[2] Blaxhall P.C., Chromosome karyotyping of fish using conventional and Gbanding methods, J. Fish Biol. 22 (1983) 417-424.

[3] Boudry P., Heurtebise S., Collet B., Cornette F., Gérard A., Differentiation between populations of the Portuguese oyster, Crassostrea angulata (Lamarck) and the Pacific oyster, Crassostrea gigas (Thunberg) revealed by mtDNA RFLP analysis, J. Exp. Mar. Biol. Ecol. 226 (1998) 279-291.

[4] Bregman A.A., Q-, C-, and G-banding patterns in the germ-line and somatic chromosomes of Miastor sp. (Diptera: Cecidomydae), Chromosoma 53 (1975) 119130.

[5] Clabby C., Goswami U., Flavin F., Wilkins N.P., Houghton J.A., Powell R., Cloning, characterisation and chromosomal location of a satellite DNA from the Pacific oyster, Crassostrea gigas, Gene 168 (1996) 205-209.

[6] Gold J.R., Li Y.C., Trypsin G-banding of North American cyprinid chromosomes: Phylogenetic considerations, implications for fish chromosome structure, and chromosomal polymorphism, Cytologia 56 (1991) 199-208.

[7] Gold J.R., Li Y.C., Chromosomal NOR karyotypes and genome size variation among squawfishes of the genus Ptychocheilus (Teleostei: Cyprinidae), Copeia 1 (1994) 60-65.

[8] Grizel H., Héral M., Introduction into France of the Japanese oyster (Crassostrea gigas), J. Cons. Int. Explor. Mer 47 (1991) 399-403. 
[9] Guo X., Allen S.K., Fluorescence in situ hybridization of vertebrate telomere sequence to chromosome ends of the Pacific oyster, Crassostrea gigas Thunberg, J. Shellfish Res. 16 (1997) 87-89.

[10] Guo X.M., Allen S.K., Sex and meiosis in autotetraploid Pacific oyster, Crassostrea gigas (Thunberg), Genome 40 (1997) 397-405.

[11] Iannuzi L., Di Meo G.P., Perucatti A., An improved characterization of goat chromosomes by means of G- and R-band comparison, Hereditas 120 (1994) 245-251.

[12] Iannuzzi L., Di Meo G.P., Perucatti A., G- and R-banded prometaphase karyotypes in goat (Capra hircus L.), Caryologia 49 (1996) 267-277.

[13] Ieyama H., Chromosomes of the oysters, Hyatissa imbricata and Dendostrea folium (Bivalvia: Pteriomorpha), Venus, Jpn. J. Malac. 49 (1990) 63-68.

[14] Insua A., Thiriot-Quiévreux C., The characterization of Ostrea denselamellosa (Mollusca, Bivalvia) chromosomes: karyotype, constitutive heterochromatin and nucleolus organizer regions, Aquaculture 97 (1991) 317-325.

[15] Insua A., Thiriot-Quiévreux C., Karyotype and nucleolus organizer regions in Ostrea puelchana (Bivalvia: Ostreidae), Veliger 36 (1992) 215-219.

[16] Ladron de Guevara B., Winkler F., Palma C., Karyotype description and the position of the nucleolar organizer region (NOR) in the Chilean oyster Tiostrea chilensis (Philippi) Chanley and Dinamani, in: Beaumont A.R. (Ed.), Genetics and Evolution of Aquatic Organisms, University of Wales, Bangor, UK, 1992, pp. 399-405.

[17] Ladron de Guevara B., Winkler F., Rodriguez-Romero F., Palma-Rojas C., Comparative karyology of four american oyster species, Veliger 39 (1996) 260-266.

[18] Leitão A., Boudry P., Labat J.P., Thiriot-Quiévreux C., Comparative karyological study of cupped oyster species, Malacologia 41 (1999) 175-186.

[19] Li X.X., Havenhand J.N., Karyotype, nucleolus organizer regions and constitutive heterochromatin in Ostrea angasi (Mollusca: Bivalvia): evidence of taxonomic relationship within Ostreidae, Mar. Biol. 127 (1997) 443-448.

[20] Littlewood D.J.T., Molecular phylogenies of cupped oysters based on partial 28S rRNA gene sequences, Mol. Phylog. Evol. 3 (1994) 221-229.

[21] Longwell A.C., Stiles S.S., Chromosomes, biology and breeding, in: Kennedy V.S., Newell R.T.E., Eble F. (Eds.), The Eastern Oyster: Crassostrea virginica, College Park Maryland, Maryland Sea Grant College XVI, 1996, pp. 443-465.

[22] Longwell A.C., Stiles S.S., Smith D.G., Chromosome complement of the American oyster Crassostrea virginica as seen in meiotic and cleaving eggs, Can. J. Genet. Cytol. 9 (1967) 845-856.

[23] Lorite P., Chica E., Palomeque T., G-banding and chromosome condensation in the ant, Tapinoma nigerrimum, Chromosome Res. 4 (1996) 77-79.

[24] Luo C., Multiple chromosomal banding in grass carp, Ctenopharyngodon idellus, Heredity 81 (1998) 481-485.

[25] Martinez-Lage A., Gonzalez-Tizon A., Méndez J., Characterization of different chromatin types in Mytilus galloprovincialis L. after C-banding, fluorochrome and restriction endonuclease treatments, Heredity 72 (1994) 242-249.

[26] Martinez-Lage A., Gonzalez-Tizon A., Méndez J., Chromosomal markers in three species of the genus Mytilus (Mollusca: Bivalvia), Heredity 74 (1995) 369-375.

[27] Méndez J., Pasantes J.J., Martinez Exposito M.J., Banding pattern of mussel (Mytilus galloprovincialis) chromosomes induced by 2xSSC/Giemsa-stain treatment, Mar. Biol. 106 (1990) 375-377.

[28] Menzel R.W., Portuguese and Japanese oysters are the same species, J. Fish Res. Board Can. 31 (1974) 453-456.

[29] O'Foighil D., Gaffney P.M., Hilbish T.J., Differences in mitochondrial $16 \mathrm{~S}$ ribosomal gene sequences allow discrimination among American [Crassostrea virginica (Gmelin)] and Asian [C. gigas (Thunberg) C. ariakensis Wakiya] oyster species, J. Exp. Mar. Biol. Ecol. 192 (1995) 211-220. 
[30] O'Foighil D., Gaffney P.M., Wilbur A.E., Hilbish T.J., Mitochondrial cytochrome oxidase I gene sequences support an Asian origin for the Portuguese oyster Crassostrea angulata, Mar. Biol. 131 (1998) 497-503.

[31] Rodriguez-Romero F., Uribe-Alcocer M., Laguarda-Figueras A., Cytogenetic study of an oyster population of the species Crassostrea virginica Gmelin from the coast of Tabasco, Mexico, Venus, Jpn. J. Malac. 37 (1978) 83-86.

[32] Rodriguez-Romero F., Laguarda-Figueras A., Uribe-Alcocer M., Rojas-Lara M.L., Distribution of " $G$ " bands in the karyotype of Crassostrea virginica, Venus, Jpn. J. Malac. 38 (1979) 180-184.

[33] Staiber W., Preferential pairing in the germ line limited chromosomes of Acricotopus lucidus (Diptera, Chironomidae), Heredity 66 (1991) 191-201.

[34] Stanyon R., Ardito G., Lamberti L., Bigatti P., The banded karyotypes of Macaca fuscata compared with Cercocebus aterrimus, Folia Primatol. 41 (1983) 137146.

[35] Sumner A.T., Chromosome Banding, Unwin Hyman Ltd, 1990.

[36] Sumner A.T., Evans H.J., Buckland R.A., New technique for distinguishing between human chromosomes, Nature 232 (1971) 31-32.

[37] Thiriot-Quiévreux C., Analyse comparée des caryotypes d'Ostreidae (Bivalvia), Cah. Biol. Mar. 25 (1984) 407-418.

[38] Thiriot-Quiévreux C., Ayraud N., Les caryotypes de quelques espèces de Bivalves et de Gastéropodes marins, Mar. Biol. 70 (1982) 165-172.

[39] Thiriot-Quiévreux C., Insua A., Nucleolar organiser region variation in the chromosomes of three oyster species, J. Exp. Mar. Biol. Ecol. 157 (1992) 33-40.

[40] Thiriot-Quiévreux C., Pogson G.H., Zouros E., Genetics of growth rate variation in bivalves: aneuploidy and heterozygosity effects in a Crassostrea family, Genome 35 (1992) 39-45.

[41] Vassart M., Séguéla A., Hayes H., Chromosomal evolution in gazelles, J. Hered. 86 (1995) 216-227. 